\title{
CONCEPTUALIZING AND SCHEMATIZING HEART METAPHORS THROUGH A COGNITIVE SEMANTIC APPROACH
}

\author{
Asnita Sirait \\ Universitas Katolik Parahyangan, Bandung \\ email: nita.seraphine@unpar.ac.id \\ Thomson Radesman Lingga \\ Universitas Kebangsaan Republik Indonesia \\ email: thomaslingga18@gmail.com
}

\begin{abstract}
Metaphor is one of interesting objects to be research for its rich cognition and use. This study aims at investigating the conceptualization of heart metaphors and to describe the image schemas of heart metaphors. The data of the study were collected from Corpus of Contemporary American English (COCA) which provides significant data relevant to the study. This is a literature study using a qualitative descriptive study through the framework of the Conceptual Metaphor Theory (CMT) proposed by Lakoff and Johnson. After the selection of metaphorical expressions of heart, the analysis was conducted to categorize the conceptual metaphor of each selected data. The image schemas were then drawn in accordance to the concept given. The study found that people mainly use metaphors to state these three types of concepts of heart metaphors, they are; HEART IS A CONTAINER, HEART IS AN OBJECT, and HEART IS HUMAN/BEING. These main concepts were then elaborated into several smaller categorizations. There are three image schemas drawn in accordance to the types of the conceptual metaphors like containment schema, compulsion schema, and removal of restraint schema. Then, image schemas are helpful to draw the mapping of abstract thing of target domain into more concrete thing of target domain.
\end{abstract}

Keywords: Conceptual metaphors, heart, image schemas, COCA, cognitive semantics

\begin{abstract}
ABSTRAK
Metafora merupakan salah satu objek yang menarik untuk diteliti karena kaya akan kognisi dan kegunaannya. Penelitian ini bertujuan untuk mengetahui konseptualisasi metafora hati dan mendeskripsikan skema citra metafora hati. Data penelitian dikumpulkan dari Corpus of Contemporary American English (COCA) yang memberikan data signifikan yang relevan dengan penelitian. Penelitian ini merupakan studi literatur dengan menggunakan studi deskriptif kualitatif melalui kerangka Conceptual Metaphor Theory (CMT) yang dikemukakan oleh Lakoff dan Johnson. Setelah pemilihan metafora ekspresi hati, analisis dilakukan untuk mengkategorikan metafora konseptual dari setiap data yang dipilih. Skema gambar kemudian digambar sesuai dengan konsep yang diberikan. Studi ini menemukan bahwa orang-orang terutama menggunakan metafora untuk menyatakan tiga jenis konsep metafora hati, yaitu; HATI ADALAH WADAH, HATI ADALAH OBJEK, dan HATI ADALAH MANUSIA. Konsep-konsep utama ini kemudian dijabarkan ke dalam beberapa kategorisasi yang lebih kecil. Ada tiga skema gambar yang digambar sesuai dengan jenis metafora konseptual seperti skema penahanan, skema paksaan, dan skema penghapusan pengekangan. Kemudian, skema gambar sangat membantu
\end{abstract}


untuk menggambar pemetaan hal abstrak dari domain target menjadi hal yang lebih konkret dari domain target

Kata Kunci: Metafora konseptual, hati, skema gambar, COCA, semantik kognitif

\section{INTRODUCTION}

Heart becomes one of human's body organs that has very significant functions. Heart is often used to symbolize human's emotion of love and affection. Anatomically, heart is defined as an organ functioning to pump blood to the entire body through blood vessel of the circulatory system (Lewis T, 2021) ${ }^{68}$. Doueihi (1997: 17) in Zhou and Jiang (2020) stated that "the heart is central to our life because it is simultaneously "the organ and symbol of the most basic and yet crucial manifestations of life"69. This supports the significant functions of heart in human's life. Scientifically, heart functions to control blood pressure and heart rate. If the heart functions failed, or called heart failure, it can lead to a fatal impact of death. Kresh and Armour (2005) in Kocica, Mladen. J.,et.al (2005) advised that 'heart should be considered as self-regulating functional system, which is greater than the sum of its constitutive parts'. 70

These important functions might lead people imaginations to compare heart to other objects of human life. One of ways to express the importance of the heart is through the use of figurative languages like metaphors of heart, metonymy of hearts, and others. In daily life, heart metaphors can be seen to convey emotion like 'to take something to heart' which means 'worried or sad' or 'heart of lion' which means bravery to save others from dangers. Then, the focus of the study would concern on the conceptual metaphor of heart in corpus-based data.

Several studies have been conducted to investigate the types of metaphors and their conceptualization through cognitive linguistics or cognitive semantics. The first study is correlated to the use of corona virus metaphors in media conducted by Sirait, A., Lingga, T., and Seva, K., (2020) entitled Conceptualizing Corona Virus Metaphor in Media Headlines: A Cognitive Semantic Approach. The study found that the most used of conceptual metaphors of corona virus is CORONA VIRUS IS A WAR71. Furthermore, the other researcher, Gong Cheng (2021) also conducted a study about heart metaphor entitled Comparison of Metaphorical Expressions of the Heart between Chinese and English. This study found that Chinese and English metaphors have similarities and difference due to the commonality of bodily experiences unique to human beings and by the discrepancy of cultural modes from different countries. The current study will focus

68 Tanya Lewis, Human heart: Anatomy, function \& facts, https://www.livescience.com/34655-humanheart.html, (accessed on November, 28 2021)

${ }^{69}$ Shifang Zhou and Xiangyoung Jiang, A Corpus-Based Contrastive Study of HEART Metaphor in Chinese and English, International Journal of Language and Linguistics 7 (3)

${ }^{70}$ Mladen, J. K., et al., Towards new understanding of the heart structure

${ }^{71}$ Asnita, S., et.al, Conceptualizing Corona Virus

Metaphor in Media Headlines: A Cognitive Semantic Approach. English Journal Literacy Utama, 5(1), 278286 
on analyzing heart metaphors, how they are conceptualized and schematized through the use of cognitive semantic approach. 72

Therefore, this study aims to investigate how heart is used metaphorically, how heart is conceptualized and schematized in Corpus of Contemporary American English (COCA) ${ }^{73}$ using cognitive semantic approach. This study expects to give wider understanding of how people use metaphor in their cognition.

\section{LITERATURE REVIEW}

After a series of pre-research activities like deciding source of the data and the selection of data, the study is continued to describe the theory used to analyze the data.

\section{COGNITIVE SEMANTICS}

When somebody said, "I keep your yours in my heart", the hearers might draw in their mind that the heart is like a container which can save or keep something. Then they understand the literal meaning of the utterance is that the speaker remembered his/her partner's utterance. This is related to the use of cognitive semantics which concerns with human's cognition and mind. Cognitive semantics is a an approach of cognitive linguistics which depicts how people conceive the world. Evans and Green (2006) concerned that cognitive semantcs is a manifestation of conceptual structure: the nature and organization of mental representation in all its richness and diversity, and this is what makes it a distinctive approach to linguistic meaning ${ }^{74}$. The area of study known as cognitive semantics is concerned with investigating the relationship between experience, the conceptual system and the semantic structured encoded by language. They continued that cognitive semantics sees linguistic meaning as a manifestation of conceptual structure: the nature and organization of mental representation in all its richness and diversity, and this is what makes it a distinctive approach to linguistic meaning.

\section{METAPHORS AND CONCEPTUAL METAPHORS}

A Metaphor is a part of figurative languages that is used to convey something with different words. Lakoff and Johnson (1980:4) stated, "Metaphor is pervasive in everyday life, not just in language but in thought and action ${ }^{75}$." This means that metaphor is not only found in written form of fiction writing or literature. To convey people's expression, there is sometimes needed a language that has deeper meaning or conveyed in other words. For instance, to say that time is really important, people often stated 'Time is money' to depict the price someone has to pay for the cost of minutes to hours. Gibbs (1999b: 145) stated that "Many concepts, especially abstract

\footnotetext{
72 Shifang Zhou and Xiangyoung Jiang, loc. cit.

73 Corpus of Contemporary American English (COCA) accessed from https://www.english-corpora.org/ coca/

${ }^{74}$ Vyvyan Evans and Melanie Green, Cognitive Linguistics: An Introduction, Routledge

75 George Lakoff and Mark Johnson, Metaphors We Live by. Chicago and London: Chicago University Press.
} 
ones, are structured and mentally represented in terms of metaphor ${ }^{76}$. To concretize abstract thing, metaphor is often used to conceptualize in order that the message is captured.

A conceptual metaphor is a concept drawn from a metaphorical expression to understand one domain to another domain which is called source domain to target domain. To understand the metaphorical expression, a mapping is drawn from an abstract domain to more concrete domain. This is supported by what Kovecses (2010:4) stating that a conceptual metaphor consists of two conceptual domains, in which one domain is understood in term of another ${ }^{77}$. A concept which belongs to a certain level of the system is understood in terms of another concept which belongs to another level of the system, no matter whether people use a source domain at the lower level to map onto a target domain at the higher level or from a higher-level map onto a lower level. For instance, Sirait, A., Lingga, T.R., Seva, K. (2020) provided one example of conceptual metaphor of COMPANY IS A PERSON78. In this concept, the source domain is a person and the target is a company to concretize the structure of a company.

\section{MAPPING}

Evans and Green (2006:167) stated, "One of prominent themes in cognitive semantics is the idea of conceptual mappings ${ }^{79}$." Furthermore, Kovecses (2010:7) said that "to understand" an abstract concept, mapping is used to characterize the relationship between two concepts (A and B) in the metaphorical process. One abstract thing is mapped onto more concrete thing to give clear depiction. One of examples that can be seen in the use of mapping is the mapping of LOVE IS A JOURNEY. Evans and Green (2006) provided one tabulation of the use of LOVE IS A JOURNEY through metaphorical expressions seen below.

- We're at the cross road

- We're spinning our wheels

- Our relationship went off course

- Our marriage is on the rock

Table 1. LOVE IS A JOURNEY Mapping

\begin{tabular}{|llll|}
\hline Source: Journey & Mapping & \multicolumn{1}{c|}{ Target: Love } \\
\hline The travellers & $\rightarrow$ & the lovers \\
The vehicle & $\rightarrow$ & the love relationship itself \\
The journey & $\rightarrow$ & events in the relationship \\
The distance covered & $\rightarrow$ & the progress made \\
The obstacles encountered & $\rightarrow$ & the difficulties experienced \\
Decisions about way to go & $\rightarrow$ & choices about what to do \\
The destination of the journey & $\rightarrow$ & the goals of the relationship. \\
\hline
\end{tabular}

${ }^{76}$ Raymond W. Gibbs, Taking Metaphor out of Our Heads and Putting it into the Cultural World.

77 Kovecses, Metonymy, Developing a cognitive linguistic approach. Cognitive Linguistics

${ }^{78}$ Asnita Sirait, et.al., loc. cit.

${ }^{79}$ Vyvyan Evans and Melanie Green, op. cit. 167 


\section{IMAGE SCHEMAS}

Lakoff and Johnson (1980) in Evans and Green (2006:300) argued that image schemas could function as source domains for metaphorical mapping. ${ }^{80}$ In the following table, several image schemas are provided which is taken from Evans and Green (2010:190).

Table 2. A partial list of image schemas

\begin{tabular}{|l|l|}
\hline Space & $\begin{array}{l}\text { up-down, front-back, left-right, near-far, centre- } \\
\text { periphery, contact, straight, verticality }\end{array}$ \\
\hline Containment & container, in-out, surface, full-empty, content \\
\hline Locomotion & momentum, source-path-goal \\
\hline Balance & $\begin{array}{l}\text { axis balance, twin-pan balance, point balance, } \\
\text { equilibrium }\end{array}$ \\
\hline Force & $\begin{array}{l}\text { compulsion, blockage, counterforce, diversion, } \\
\text { removal of restraint, enablement, attraction, } \\
\text { resistance }\end{array}$ \\
\hline unity/multiplicity & $\begin{array}{l}\text { merging, collection, splitting, iteration, part-whole, } \\
\text { count-mass, link (age) }\end{array}$ \\
\hline Identity & matching, superimposition \\
\hline Existence & removal, bounded space, cycle, object, process \\
\hline
\end{tabular}

\section{RESEARCH METHODOLOGY}

This study applied a qualitative descriptive methodology to analyze the data supported by library research. In qualitative descriptive study, an investigator becomes the central of the study plays a dominant role in deciding which data is going to take (Bogman and Biklen, 1992:36) ${ }^{81}$. The data were obtained from Corpus of Contemporary American English (COCA), which is scoped to heart metaphor. The intended data were downloaded from https://www.english-corpora.org/coca/. The writers considered corpus as the source of the data because of the abundance of data that a corpus can provides. Sinclair $(2005: 16)$ states that a corpus is a collection of pieces of language text in electronic form, selected according to external criteria to present abundant data for language varieties or usages ${ }^{82}$. The benefit of using corpus linguistic in research is promoted by Compoy-Cubillo, Belles-Fortuno and Gea-Valor (2010:3). It is stated that research in corpus linguistics has enabled the expansion of better-quality learner's input and manage to provide researchers with a wider, finer perspective into language in use. The algorithms of analyzing the data were described in the following:

\footnotetext{
${ }^{80}$ Vyvyan Evans and Melanie Green, op. cit. 300

${ }^{81}$ Bogman \& Biglen, Qualitative Research for Education - An Introduction to Theory and Methods. Allya and Bacon: Boston and London.

82 John Sinclair, Corpus, concordance, collocation. Oxford University Press
} 
1. The data were firstly download from Corpus of Contemporary American English (COCA).

2. The writers selected several representative data contained heart metaphors.

3. The selected data were then analyzed using of conceptual metaphors proposed by George Lakoff and Mark Johnson in their 1980 Metaphors We Live By to identify the conceptual metaphor which is supported by Kovecses (2010) saying that the concept of conceptual source domain is conceptual target domain, which is called conceptual metaphor.

4. The writers then draw the image schemas used in the conceptual metaphors using Lakoff and Johnson theory, supported by John I Saeed, who divided schemas into three; containment schemas, path schemas, and force schemas.

5. Having accomplished the analysis, conclusion is drawn to see the use of metaphor and its concept in cognitive semantic approach.

\section{FINDING AND DISCUSSIONS}

In advance to the selection of the data, they were then analyzed using Conceptual Metaphor Theory (CMT). There are several metaphorical expressions chosen to represent those of metaphors of heart found in COCA. After a mindful consideration, there were found some heart metaphors which are then classified according to their conceptualization. In accordance to their concept, image schemes are drawn to show how metaphors are conceptualized through cognitive semantic approach. The finding and discussion can be seen below.

\section{A. HEART IS A CONTAINER}

This conceptualization is taken from the characteristic of a container which can hold or save an entity or containment. A container is something which can be used for holding or keeping or saving an entity in which freight is place for convenience of movement, (Merriam Webster Dictionary) ${ }^{83}$. Lakoff and Johnson (1980:29) stated that a containment metaphor belongs to an ontological metaphor which has an inside and outside, and something that can hold something else $^{84}$. In the following expressions, heart is regarded or conceptualized as a container that can hold different entity in it.

Datum 1: and like the strange liquids of necromancers, descended to the very depths of his heart.

$$
\text { (99928, 2014 FIC EnglishLit Transition) }
$$

'Descend to the very depths of his heart' might be depicted as an entity which is going deep down to a base of a container that it is hard for it to get out or difficult for somebody else to take it out. So, heart here is depicted as a container which can be used to save something. When saying 'descend to the very depths of his heart', the speaker might map his heart as a container to put a thing safe.

\footnotetext{
${ }^{83}$ Merriam Webster Dictionary accessed from https://www.merriam-webster.com/

84 George Lakoff and Mark Johnson, opt. cit. 29
} 
Datum 2: from the earth, and inside his heart was a sun-dappled forest, where he saw a pack of dogs running free.

$$
\text { (99942 2014 FIC ParisRev) }
$$

Another example of metaphorical expression is given in the above statement. This metaphorical expression depicted mood condition of a person who was happy or joyful that it contained a sundappled forest. To comprehend this mood condition, a heart is mapped onto a container which is very large to hold big entity.

Johnson, M. (1987:21ff) proposed an image schema of containment which is drawn from human's bodily experience of being physically located ourselves within bunded locations like rooms, beds, etc,; and also putting objects into containers ${ }^{85}$. This image can be seen below.

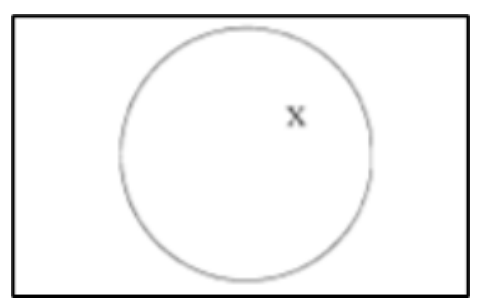

Figure 1: Containment Schemas (Source: Mark Johnson (1987:27))

Datum 3: than ever. But cooking is art that comes from the heart, and his heart is troubled.

$$
\text { (99934 } 2014 \text { FIC JHumanMath) }
$$

This datum is similar to previous datum that the heart is conceptualized as a container which can hold or save something in. The use of preposition 'from' shows that the heart is made as the concept of a place of an entity's previous location.

To describe more on how this conceptual metaphor is depicted, an image schema is drawn which applied COMPULSION schema. This image scheme shows something that appears from the experience of being moved by external force. Here is the figure:

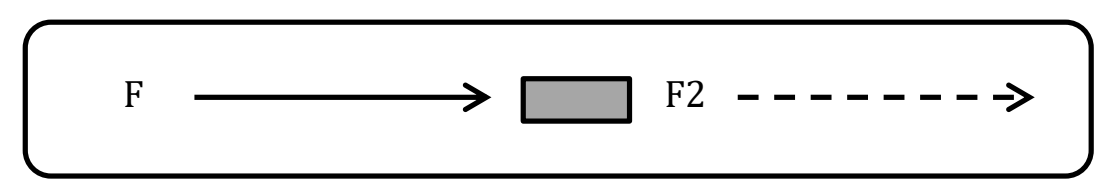

Figure 2: Compulsion schema

From the phrase 'art that comes from the heart', it shows that an entity (described as 'art') moves from one trajectory to another point due to an internal force; and the dashed line could mean the force may be blocked or stopped or even continue to the other trajectory.

85 Mark Johnson, The Body in the Mind. The Bodily Basis of Meaning, Reason and Imagination. Chicago: Chicago University Press. 


\section{B. HEART IS AN OBJECT}

An object is something or a material which can be perceived by the senses, it can be abstract or concrete. In line with the object meaning, in the following expressions, heart is described or analogized as an object with different characteristics.

i. HEART IS A FRAGILE OBJECT

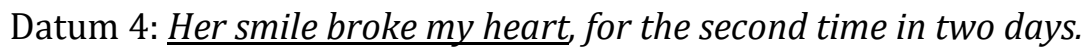

$$
\text { (99917 } 2014 \text { FIC FantasySciFi) }
$$

Datum 5: ... people project onto me, "said Luc. "Lust don't break her heart, okay? "

This concept is drawn from the source of a fragile things which is breakable to understand how the heart is broken through a smile. The literal meaning of 'broke one's heart' is 'to cause someone to feel great sorrow or sadness' (Merriam Webster).

Data 4 and 5 show that heart is described as something that is fragile or easily breakable. To understand the state of 'heart fragility', a concept is then drawn to a condition of a more breakably visible object.

\section{ii. A HEART IS BURNABLE/INFLAMMABLE OBJECT}

Datum 6: Her heart was hot, and tears lay near the surface when she heard the shouts to...

$$
\text { (999552014 FIC FantasySciFi) }
$$

'Her heart was hot' shows a condition that someone is emotionally angry to something or someone else. To understand one's emotion, this metaphorical expression is mapped onto an object that can be burnt or easily inflamed or angered. The source domain here is the inflammable object and the target domain is the heart. When the target is an abstract concept, a more concrete object can be used as the bridge to say or express the conceptual external image of the abstract entity.

iii. A HEART IS A DELICACY

Datum 7: ... that people say don't exist. " We kiss until I learn what a heart tastes like. "

$$
\text { (997462 } 014 \text { FIC FantasySciFi) }
$$

The use of a dependent clause of 'what a heart tastes like' is metaphorically used to express a passionate emotion. This abstract emotion is the mapped on to a more concrete object, a delicacy. The sweetness that is felt by falling in love couples is then conceptualized to something that has a sweet taste.

\section{HEART IS A HUMAN/BEING}

The following conceptualization of heart metaphors is mapped from the characteristics of human or other beings which can move from one place to another site by walking, running, jumping, leaping, racing, other activities which show the movement of transferring from one place to another. The following analyses can be seen below. 


\section{i. A HEART IS AN AGILE PERSON/BEING}

Datum 8: Her heart jumped. Lots of details to be worked out, but land, she felt.

(99920 2014 FIC Commentary)

In this statement, the heart is depicted as a being which can leap or jump. Literally this means that someone is very happy or joyful that she/she might feel his/her heart leap. To understand the concept of this metaphorical expression, a mapping from the source domain of human or other being's ability to jump to the target domain 'heart' ability to jump because of joyful feeling. In this concept, jumping heart is understood through a more concrete object's capability to leap.

\section{Datum 9: My heart might have leaped with a thrill of sheer dislike of the old woman,}

\section{(998262014 FIC KenyonRev)}

This concept is similarly used as the previous datum. 'Heart' here is depicted as a being that has a capability of jumping/leaping or moving from one place to another place. The agility of heart here may mean a sudden move due to an external force. To make it more concrete, human or being's ability to move is mapped onto the target domain 'heart' to make it more understandable.

Datum 10: My heart is racing, the net face mask fluttering as I try to exhale slowly.

Besides jumping and leaving, the agility of living or being's movement can be shown in another material process of 'racing'. Heart's race is conceptualized from the how human races from one place to another place in a fast pace. 'My heart is racing' literally means that one's heart is beating faster because of happiness, excitement, or surprise.

This conceptual metaphor can be schemed through path image schema.

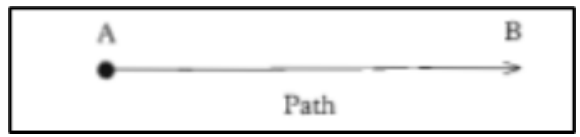

Figure 3: Path Schema (Source: Mark Johnson (1987:114))

A path schema comprises a starting point (A) and an end point (B). While racing, the runner would start from a start point and make an effort to reach the finish line. The two locations are marked by the arrow $(A \rightarrow B)$. The PATH schema can be understood as an object move from one place to another consisting of a starting point to a goal line.

Saeed (1997: 378) explained a number of associated implications from the above schema:

a. Since A and B are connected by a series of contagious locations, getting from A to B implies passing through the intermediate points.

b. Paths tend to be associated with directional movement, alog them, say from A to B.

c. There is an association with the time. Since a person travelling a path takes time to do so, points on the path are readily associated with temporal sequence ${ }^{86}$.

${ }^{86}$ John I Saed, Semantics. 2th Edition. Blackwell Publishing. Australia 
From this point, the path schema described in this concept is relevant in the movement from one point (A) to another point (B).

\section{ii. A HEART IS AN EMOTIONAL HUMAN}

Datum 11: but his heart was cold and sad.... After dinner, when the Burgomaster began to snore,

$$
\text { (99930 } 2014 \text { FIC EnglishLitTransition) }
$$

The clause 'but his heart was cold and sad' used human's mood or attitude as a vehicle to understand the mood of the heart. Literally, the clause might mean that he felt lacking affection or warmth or unloving'. This metaphorical expression of heart emotion 'cold and sad' is conceptualized to human's emotion 'unloving or unsympathetic'.

Datum 12: I tell myself, but my heart still cries out for the beauty he's losing.

$$
\text { (999742014 FIC FantasySciFi) }
$$

The part 'my heart still cries out' is analogous to the attitude of a human that cried in time he/she felt sad. The clause 'my heart still cries out' means that someone made a loud voice or sound due to unbearable pain or fear. To figuratively convey people's state, metaphorical expression works. This abstract concept is bridged by a mapping from human's behaviour to heart's behaviour in an saddening or surprising emotional state.

\section{iii. A HEART IS A FLYING BEING/BIRD}

Datum 13: I felt my heart fly up into my mouth. When Ghlem crouched and leaped after the tad,

$$
\text { (99976 2014FIC FantasySciFi) }
$$

A flying being or a bird is borrowed to conceptualize how heart flies up into a place. This expression means an unexpected feeling of blood rush to the neck which may signal that someone is going to be sick. The ability of bird to fly is mapped onto the heart sudden force to go up.

To illustrate the image schema of this mapping, the FORCE image of REMOVAL OF RESTRAINT can be used. This shows a circumstance where an obstruction to force is removed, allowing energy to be released. This illustrates a situation like leaning on a door that suddenly opens. Here is the figure:

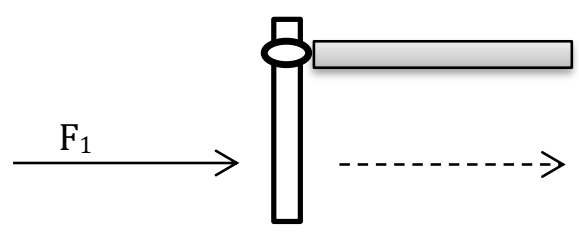

Figure 4: Removal of restraint schema 
The sudden force of the phrase 'heart fly up into my mouth' can be illustrated a situation that a force is suddenly popping out of something after being restrained or stopped for some time.

\section{CONCLUSION}

After analyzing the data, there are found three main conceptual metaphors of heart in coca. This finding represented 200 data which were downloaded from https://www.englishcorpora.org/coca/; they are; HEART IS A CONTAINER, A HEART IS AN OBJECT, and HEART IS HUMAN/BEING. These main concepts were then elaborated into several concept; they are HEART IS A CONTAINER, HEART IS A FRAGILE OBJECT, A HEART IS BURNABLE/INFLAMMABLE OBJECT, A HEART IS AN AGILE PERSON/BEING, A HEART IS AN EMOTIONAL HUMAN, and A HEART IS A FLYING BEING/BIRD. From 200 data downloaded, the most use of conceptual metaphors is A HEART IS AN OBJECT. There are three image schemas drawn in accordance to the types of the conceptual metaphors. The schemas used are containment schema, compulsion schema, and removal of restraint schema.

These metaphorical conceptualizations help the readers or listeners to understand the meaning of certain contained in metaphorical expressions. Conceptualizations are beneficial in comprehending abstract concepts to more concrete concepts and provide cognition and knowledge to be applied to some more abstract models. Furthermore, the use of corpus in linguistic research is useful because of the abundant data it can provide. Due to the data convenience of provision, this corpus is suggested to be used. Therefore, further research needs to be conducted to see other variations in heart metaphors and other conceptual metaphors, the comparison of cultural use of metaphors, and other object besides heart metaphors.

\section{REFERENCES}

Ahn H. J \& Kwon Y. J. (2007) A Study on Metaphor and Metonymy of Hand (Journal of Language ciences

Bogman \& Biglen. (1992). Qualitative Research for Education - An Introduction to Theory and Methods. Allya and Bacon: Boston and London

Cheng, Gong. (2021). Comparison of Metaphorical Expressions of the Heart between Chinese and English. English Language Teaching; Vol. 14, No. 3. URL: https://doi.org/10.5539/ elt.v14n3p25

Doueihi, M. (1997). A Perverse History of the Human Heart. Cambridge, MA: Harvard University Press.

Evans Vyvyan and Green Melanie (2006). Cognitive Linguistics: An Introduction. Routledge

Gibbs, R. \& T. Matlock. (2006). Psycholinguistics and mental representation, Cognitive Linguistics.

Gibbs, R. (1999) Taking Metaphor out of Our Heads and Putting it into the Cultural World. In Gibbs, R. and G. Steen (eds.), Metaphor in Cognitive Linguistics. John Benjamins, Amsterdam

Lakoff, George, and Johnson, M. 1980.Metaphors we live by. Chicago: University of Chicago. 
Johnson, M. (1987) The Body in the Mind. The Bodily Basis of Meaning, Reason and Imagination. Chicago: Chicago University Press.

Johnson, M. (1992) Philosophical Implications of Cognitive Semantics. Cognitive Linguistics

Kövecses, Z. and Radden, G. (1998) Metonymy, Developing a cognitive linguistic approach. Cognitive Linguistics

Krzeszowski, T.P. (1993) The Axiological Parameter in preconceptional image schemata. In: R.A. Geiger and B. Rudzka-Ostyn (eds.) Conceptualisations and Mental Processing in Language. Berlin and New York: Mouton de Gruyter.

Kresh JY, Armour JA. The heart as a self-regulating system: integration of homeodynamic mechanisms. Technol Health Care 1997;5:159-69. DOI:10.1016/j.ejcts.2004.11.026

Lakoff, G. (1993) The Contemporary Theory of Metaphor. In: A. Ortony (ed.) Metaphor and Thought. Cambridge: Cambridge University Press.

Lakoff, G., Johnson, M. (1980) Metaphors We Live by. Chicago and London: Chicago University Press.

Lewis, T. (October 22, 2021). Live Science. Human heart: Anatomy, function \& facts. Accessed from .com/34655-human-heart.html

Mladen J. Kocica,.et.al. (2005) Towards new understanding of the heart structure and function. European journal of cardio-thoracic surgery: official journal of the European Association for Cardio-thoracic Surgery 27(2):191-201

Saeed, I. John. (2003). Semantics. $2^{\text {th }}$ Edition. Blackwell Publishing. Australia

Sinclair, John. (1991). Corpus, corcondance, collocation. Oxford University Press

Sinclair, John (2005). Corpus and text - basic principles in Developing Linguistic Corpora: A guide to good practice, ed. M. Wynne. Oxford: Oxbow Books

Sirait, Asnita, Seva, K., \& Lingga, T. R. (2020). Conceptualizing Corona Virus Metaphor in Media Headlines: A Cognitive Semantic Approach. English Journal Literacy Utama, 5(1), 278-286. https://doi.org/10.33197/ejlutama.vol5.iss1.2020.477

Zhou, S and Jiang, X. (2021). A Corpus-Based Contrastive Study of HEART Metaphor in Chinese and English. International Journal of Language and Linguistics Vol. 7, No. 3, September 2020 doi:10.30845/ijll.v7n3p9 